\title{
Enhanced Energy Storage Density and Excellent Thermal Stability Under Low Electric Fields of KF- added BNT-ST-AN Relaxor Ferroelectric Ceramics Prepared by the Solid-state Combustion Technique
}

Chittakorn Kornphom

Chiang Mai Rajabhat University

Kamonporn Saenkam

Chiang Mai University

Theerachai Bongkarn ( $\nabla$ researchcmu@yahoo.com )

Naresuan University

\section{Research Article}

Keywords: BNT-ST-AN, combustion technique, phase formation, high energy storage, relaxor ferroelectric

Posted Date: December 20th, 2021

DOI: https://doi.org/10.21203/rs.3.rs-1159872/v1

License: (c) (1) This work is licensed under a Creative Commons Attribution 4.0 International License.

Read Full License 


\title{
Enhanced energy storage density and excellent thermal stability under low electric fields of KF-added BNT-ST-AN relaxor ferroelectric ceramics prepared by the solid-state combustion technique
}

\author{
C. Kornphom ${ }^{\mathrm{a}}$, K. Saenkam ${ }^{\mathrm{b}}$, T. Bongkarn ${ }^{\mathrm{c}, \mathrm{d} *}$ \\ ${ }^{a}$ Department of Physics and General Science, Faculty of Science and Technology, Chiang Mai Rajabhat University, \\ Chiang Mai, 50300, Thailand \\ ${ }^{b}$ Department of Physics and Materials Science, Faculty of Science, Chiang Mai University, \\ Chiang Mai, 50200, Thailand \\ cDepartment of Physics, Faculty of Science, Naresuan University, Phitsanulok, 65000, Thailand \\ ${ }^{d}$ Research Center for Academic Excellence in Applied Physics, Faculty of Science, Naresuan University, Phitsanulok, 65000, \\ Thailand \\ *Corresponding Author’s E-mail: researchcmu@yahoo.com
}

\begin{abstract}
Homogeneous $\quad 0.722\left(\mathrm{Bi}_{0.5} \mathrm{Na}_{0.5} \mathrm{TiO}_{3}\right)-0.228\left(\mathrm{SrTiO}_{3}\right)-0.05\left(\mathrm{AgNbO}_{3}\right) \quad$ (BNT-ST-AN) ceramics with various amounts of potassium fluoride (KF) added were prepared by the solidstate combustion technique. The ceramics presented a single perovskite phase with coexisting rhombohedral $(\mathrm{R})$, cubic $(\mathrm{C})$ and orthorhombic $(\mathrm{O})$ phases. The amount of the $\mathrm{R}$ phase decreased while the percentage of the $\mathrm{C}+\mathrm{O}$ phase increased when $\mathrm{KF}$ addition increased from 0.0 to $3.0 \mathrm{~mol} \%$. The smallest grain size, the highest density and maximum dielectric constant $\left(\varepsilon_{\mathrm{m}}\right)$ were achieved with a KF addition of $1.5 \mathrm{~mol} \%$. Following this design composition of the ceramics, the highest recoverable energy-storage density $\left(\mathrm{W}_{\text {rec }} \sim 1.60 \mathrm{~J} / \mathrm{cm}^{3}\right)$ and $\eta$ above $85.8 \%$ at a low electric field $(100 \mathrm{kV} / \mathrm{cm})$ were obtained from BNT-ST-AN with KF addition at 1.5 mol\% because this composition contained a morphotropic phase boundary (MPB) region and had the smallest grain size, which gave the lowest remnant polarization $\left(\mathrm{P}_{\mathrm{r}}\right)$ and a large maximum polarization $\left(\mathrm{P}_{\mathrm{m}}\right)$. Additionally, BNT-ST-AN with $\mathrm{KF}$ addition at $0.15 \mathrm{~mol} \%$ exhibits stability over a wide range of temperatures $\left(25-150^{\circ} \mathrm{C}\right)$ at a low electric field $(100$ $\mathrm{kV} / \mathrm{cm}$ ), which shows great potential in pulse-power system applications.
\end{abstract}


Keywords: BNT-ST-AN, combustion technique, phase formation, high energy storage, relaxor ferroelectric

\section{Introduction}

Since the discovery of electricity, many devices to store electrical energy have been invented. Over the last century, the electronic industry has continued to improve energy storage devices and produce new innovative devices in response to changing energy requirements and advances in technology. Energy storage systems provide a technological way to manage electrical power supply, producing a more resilient energy infrastructure and bringing cost savings to utilities and consumers ${ }^{1}$.

Currently, many different energy storage devices are being developed and continuously optimized for electrical energy storage solutions. Dielectric capacitors are one of the more suitable devices for electric vehicles, pulsed power systems, and renewable energy-storage devices because of their ultrahigh power density, excellent endurance and almost unlimited lifetime ${ }^{2,3}$. However, dielectric capacitors are limited in applications as energy storage devices due to their large volume and weight to provide sufficient output energy, which is a barrier for use in lightweight and miniaturized pulse power devices ${ }^{4,5}$. Consequently, the development of dielectric materials with a high energy storage density $(\mathrm{W})$ is a highly popular research topic.

The lead-free perovskite ferroelectric ceramics of bismuth sodium titanate $\left(\mathrm{Bi}_{0.5} \mathrm{Na}_{0.5} \mathrm{TiO}_{3}\right.$ or $\left.\mathrm{BNT}\right)$ have been predicted as a potential energy storage material owing to their large spontaneous polarization $\left(\mathrm{P}_{\mathrm{S}}\right)$ of $>40 \mu \mathrm{C} / \mathrm{cm}^{2} 6,7$, which derives from the hybridization of Bi $6 \mathrm{p}$ and $\mathrm{O} 2 \mathrm{p}$ orbitals ${ }^{7}$. However, the BNT ceramic exhibited large remnant polarization $\left(\mathrm{P}_{\mathrm{r}}\right)$ and a high coercive field $\left(\mathrm{E}_{\mathrm{c}} \sim 73 \mathrm{kV} / \mathrm{cm}\right)$ at room temperature ${ }^{6-8}$, which led to energy-storage property deterioration (a small recoverable energy storage density; $\mathrm{W}_{\text {rec }}$ and a low energy storage efficiency; $\eta)^{4,7-9}$. Moreover, the $\mathrm{P}_{\mathrm{r}}$ values can be greatly decreased by compositional design with a small grain size and diffuse phase transition, which leads to an 
increase in the effective polarization values and an increase in the $\mathrm{W}_{\text {rec }}$ values of BNT ceramics ${ }^{6-12}$. For example, C. Zhu et al. ${ }^{12}$ reported that an ultrahigh $\mathrm{W}_{\text {rec }}$ of $5.55 \mathrm{~J} / \mathrm{cm}^{3}$ and $\eta$ above $85 \%$ were obtained from a $0.8\left(0.95 \mathrm{Bi}_{0.5} \mathrm{Na}_{0.5} \mathrm{TiO}_{3}-0.05 \mathrm{SrZrO}_{3}\right)-0.2 \mathrm{NaNbO}_{3}(\mathrm{BNTSZNN})$ ceramic, which was prepared by two-step sintering and using a fast heating rate of $60^{\circ} \mathrm{C} / \mathrm{min}$. Next, W.P. Cao et al. ${ }^{13}$ observed that $(1-\mathrm{x})\left(\mathrm{Na}_{0.5} \mathrm{Bi}_{0.5}\right) \mathrm{TiO}_{3}-\mathrm{xSrTiO}_{3}(\mathrm{NBT}-\mathrm{ST})$ at an $\mathrm{x}$ content of 0.3 exhibited excellent temperature stability in its energy-storage properties from room temperature up to $120^{\circ} \mathrm{C}$. The highest $\mathrm{W}_{\text {rec }}$ value of $0.65 \mathrm{~J} / \mathrm{cm}^{3}$ was obtained at $65 \mathrm{kV} / \mathrm{cm}^{13}$. Then, W. Ma et al. 14 investigated novel lead-free relaxor ferroelectric (1$\mathrm{x})\left(0.76 \mathrm{Bi}_{0.5} \mathrm{Na}_{0.5} \mathrm{TiO}_{3}-0.24 \mathrm{SrTiO}_{3}\right)-\mathrm{xAgNbO}_{3}$ ceramics with $\mathrm{x}=0-9 \mathrm{~mol} \%$ at the morphotropic phase boundary (MPB) zone, prepared by the solid-state reaction technique (calcined at $800^{\circ} \mathrm{C}$ for $8 \mathrm{~h}$ and sintered at $1150^{\circ} \mathrm{C}$ for $3 \mathrm{~h}$ ). They reported that a large $\mathrm{W}_{\text {rec }}$ of $1.42 \mathrm{~J} / \mathrm{cm}^{3}$ was obtained from $0.722\left(\mathrm{Bi}_{0.5} \mathrm{Na}_{0.5} \mathrm{TiO}_{3}\right)-0.228\left(\mathrm{SrTiO}_{3}\right)-0.05\left(\mathrm{AgNbO}_{3}\right)(\mathrm{BNT}-\mathrm{ST}-$ $\mathrm{AN}$ ) at a low electric field of $100 \mathrm{kV} / \mathrm{cm}$, which is superior to other lead-free energy storage materials under similar electric fields ${ }^{14}$. However, producing BNT-based relaxor ferroelectric ceramics with a solid-state reaction and two-step sintering, which uses high firing temperatures and long dwells, causes the evaporation of $\mathrm{Bi}^{+}\left(\sim 825^{\circ} \mathrm{C}\right)$ and $\mathrm{Na}^{+}\left(\sim 1132^{\circ} \mathrm{C}\right)$ during the firing process ${ }^{15,16}$. The inevitable volatilization of $\mathrm{Bi}^{+}$and $\mathrm{Na}^{+}$during the firing process causes cation vacancies, as well as oxygen vacancies, as explained by the Kröger-Vink defect equation (Eq. 1 and 2) ${ }^{15,16}$.

$$
\begin{aligned}
& 2 N a_{N a}^{x}+O_{O}^{x} \rightarrow 2 V_{N a}^{\prime}+V_{O}^{\ddot{*}}+N a_{2} O(g) \\
& 2 B i_{B i}^{x}+3 O_{O}^{x} \rightarrow 2 V_{B i}^{\prime \prime \prime}+3 V_{O}^{*}+B i_{2} O_{3}(g)
\end{aligned}
$$

The volatilization of $\mathrm{Na}^{+}$and $\mathrm{Bi}^{3+}$ disrupts the stoichiometric ratio of the BNT-ST-AN composition and generates oxygen vacancies that induce a large leakage current under high electric fields, a lower breakdown potential and a reduced energy storage density ${ }^{12-14}$. To reduce oxygen vacancies in lead-free ferroelectric ceramics, Y. Liao et al. ${ }^{17}$ reported that the 
doping of fluorine (F) into $\mathrm{K}_{0.5} \mathrm{Na}_{0.5} \mathrm{Nb}_{0.996} \mathrm{Cu}_{0.01} \mathrm{O}_{3}-\mathrm{Fx}(\mathrm{KNCNF}-\mathrm{x})$ ceramics at $\mathrm{x}=0.28$ can promote a reduction in grain size and $\mathrm{P}_{\mathrm{r}}$ value due to the formation of $F_{O}^{\bullet}$ point defects substituted in oxygen vacancies $\left(\mathrm{O}^{2-}\right)$ of perovskite structures, which mainly improved the energy storage properties of the ceramics.

From the literature reviews, it is observed that the phase structural design, sintering procedure and compound doping are all important steps to optimize the densification, small grain size and energy storage performance of BNT-based relaxor ferroelectrics ${ }^{6,7,9,11-16,18-20}$. It has become popular to add some compounds with a low melting point in BNT-based ceramics to also improve their density and electrical performance, as they help the formation of the liquid phase ${ }^{16}$. A typical sintering aid, potassium fluoride (KF), has been widely used in various ceramic materials ${ }^{16}$ owing to its low melting point of $858^{\circ} \mathrm{C}$, which leads to decreased sintering temperatures. Additionally, KF can supply excess $\mathrm{K}^{+}$and $\mathrm{F}^{-}$ions into BNTbased ceramics. $\mathrm{K}^{+}$can compensate for the loss of $\mathrm{Na}^{+}$at A-sites in BNT-based ceramics during the firing process due to the similar ionic radii between $\mathrm{K}^{+}(2.33 \AA)$ and $\mathrm{Na}^{+}(1.90 \mathrm{~nm}){ }^{15,16}$.

Therefore, in this work, the addition of KF to BNT-ST-AN ceramics prepared by the solid-state combustion technique, which is simple, has a low cost and produces highperformance lead-free piezo-ceramics with low firing temperatures ${ }^{21,22,}$ was investigated. Moreover, from a survey of the literature, the effect of KF addition on the phase formation, dielectric property, ferroelectric property and energy storage density of BNT-ST-AN ceramics prepared by the solid-state combustion method has rarely been studied. In this paper, we studied the effect of $\mathrm{KF}$ addition on the phase formation, microstructure, dielectric property, ferroelectric property and energy storage density. The introduction of $\mathrm{F}^{-}$ions is expected to reduce oxygen vacancies in BNT-based ceramics, as mentioned above. 


\section{Experiment procedure}

Ceramics $\left(0.722\left(\mathrm{Bi}_{0.5} \mathrm{Na}_{0.5} \mathrm{TiO}_{3}\right)-0.228\left(\mathrm{SrTiO}_{3}\right)-0.05\left(\mathrm{AgNbO}_{3}\right)(\mathrm{BNT}-\mathrm{ST}-\mathrm{AN})\right)$ with various KF additions were prepared by the solid-state combustion technique using glycine $\left(\mathrm{C}_{2} \mathrm{H}_{5} \mathrm{NO}_{2}\right)$ as fuel. The raw materials used were high purity reagent grade powders of $\mathrm{Bi}\left(\mathrm{NO}_{3}\right)_{3} .5 \mathrm{H}_{2} \mathrm{O}(99 \%), \mathrm{Na}\left(\mathrm{NO}_{3}\right)(99 \%), \mathrm{TiO}_{2}(99 \%), \mathrm{SrCO}_{3}(99.0 \%), \mathrm{Ag}_{2} \mathrm{O},(99 \%) \mathrm{Nb}_{2} \mathrm{O}_{5}$ (99.0\%) and $\mathrm{C}_{2} \mathrm{H}_{5} \mathrm{NO}_{2}(95.0 \%)$. Before weighing, the oxides and carbonate of raw materials were baked at $120^{\circ} \mathrm{C}$ for at least $24 \mathrm{~h}$. All raw materials were weighed according to the stoichiometric composition for BNT-ST-AN and ball milled in ethanol for $24 \mathrm{~h}$. Then, the slurries were dried, the dried powders were mixed with glycine at a ratio of 1:2, and the mixed powders were calcined at $750^{\circ} \mathrm{C}$ for $4 \mathrm{~h}$ in air. After that, the pure calcined powders were mixed with $\mathrm{KF}(99.0 \%)$ powders at $0,0.5,1.0,1.5,2.0,2.5$ and $3.0 \mathrm{~mol} \%$, and all mixed calcined powders had polyvinyl alcohol added as a binder (PVA: 3 wt.\% aqueous solution) and were ball milled again for $24 \mathrm{~h}$. After remilling, all mixed calcined powders were dried and sieved with a 60 -mesh grid and then pressed into green bodies $(1.5 \mathrm{~mm}$ in thickness and $15 \mathrm{~mm}$ in diameter) under a pressure of $100 \mathrm{MPa}$. The green bodies were sintered at $1125^{\circ} \mathrm{C}$ for $2 \mathrm{~h}$ in air with a heating rate of $5^{\circ} \mathrm{C} / \mathrm{min}$ and allowed to cool naturally.

The crystalline structure of the BNT-ST-AN ceramics with various KF additions was determined by X-ray diffraction (XRD; Philips PW 3040/60 X'Pert PRO) using monochromatic $\mathrm{Cu}-\mathrm{K} \alpha$ radiation $(\lambda=1.5418 \AA)$ in the scanning range of $10^{\circ}$ to $60^{\circ}$ of $2 \theta$. For the microstructural analysis, the BNT-ST-AN ceramics with various KF additions were characterized using a scanning electron microscope (SEM, Leo, 1455VP). Before analysis by SEM, the BNT-ST-AN ceramics with various KF additions were polished and thermally etched in air at a temperature of $100^{\circ} \mathrm{C}$ below the sintering temperature for $10 \mathrm{~min}$. The average grain size of the ceramics was calculated by the linear interception method on SEM images. The densities were measured according to Archimedes' method. Theoretical densities were 
calculated based on the obtained lattice parameters and relative densities of the ceramics. To analyze the electrical properties of the ceramics, silver paste was screen printed on both surfaces of all ceramics as electrodes and dried at $400^{\circ} \mathrm{C}$ for $15 \mathrm{~min}$ for good electrical contacts. The temperature and frequency dependence of the dielectric permittivity and loss tangent were measured with an LCR meter (HP, $4284 \mathrm{~A})$ in the temperature range of $25-400^{\circ} \mathrm{C}$ at frequencies of $1-100 \mathrm{kHz}$ with a heating rate of $2^{\circ} \mathrm{C} / \mathrm{min}$. The P-E hysteresis loops of all ceramics were measured by a computer-controlled modified Sawyer-Tower circuit (Radiant, PLC2-1014346).

\section{Results and discussion}
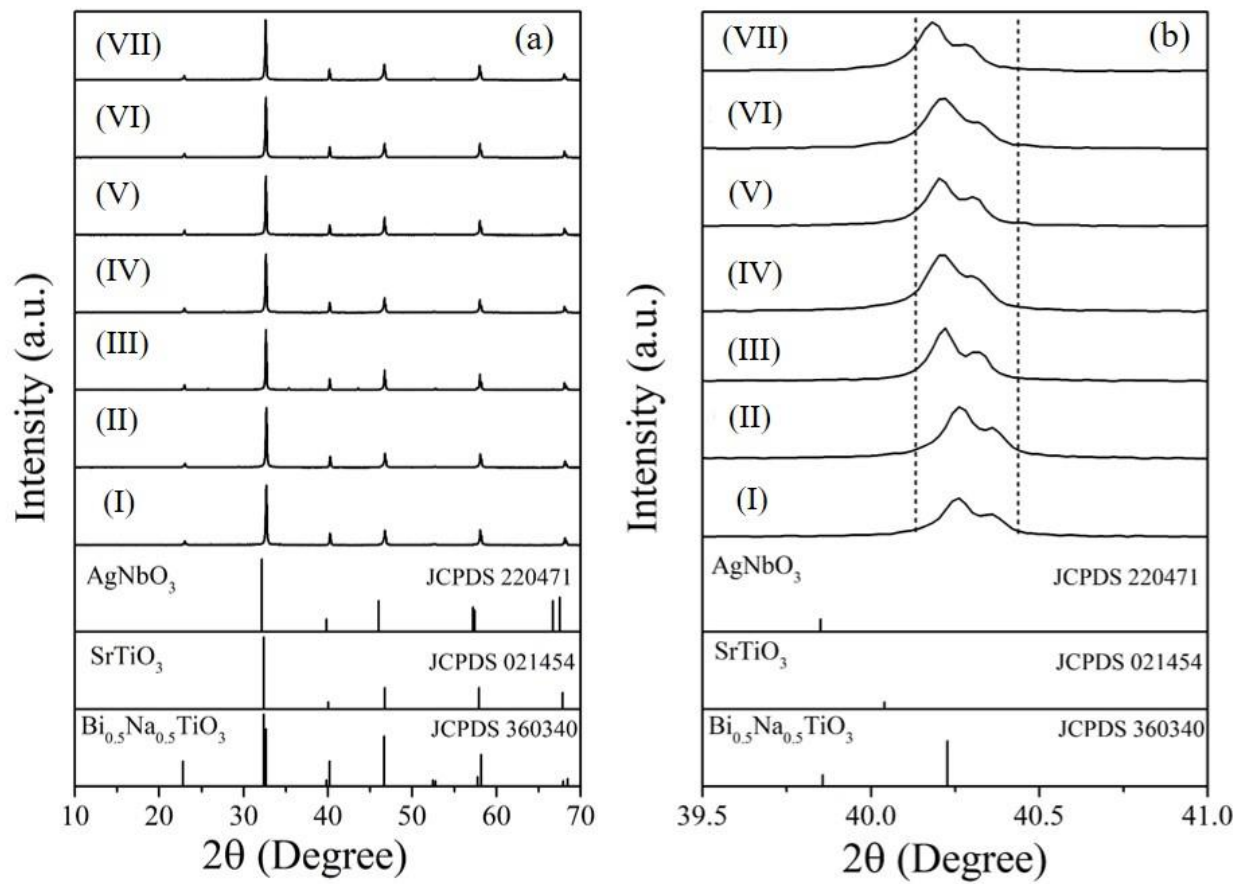

Fig. 1 XRD patterns of (a) $2 \theta$ between $10-70^{\circ}$ and (b) $2 \theta$ between $39.5-41^{\circ}$ of BNT-ST-AN ceramics with KF addition of (I) 0, (II) 0.5, (III) 1.0, (IV) 1.5, (V) 2.0 (VI) 2.5 and (VII) 3.0 $\mathrm{mol} \%$.

The X-ray diffraction patterns at $2 \theta$ between $10-70^{\circ}$ of the BNT-ST-AN ceramics with added KFs of $0,0.5,1.0,1.5,2.0,2.5$ and $3.0 \mathrm{~mol} \%$, recorded at room temperature, are shown in Fig. 1(a). All the patterns showed a single phase for the perovskite structure, which corresponded to standard JCPDS files no. 360340 (rhombohedral phase), 021454 (cubic phase) 
and 220471 (orthorhombic phase). No impurity phases were observed for any of the ceramics, which indicated that the KF completely dissolved into the lattice of the BNT-ST-AN ceramics, and a well-formed crystallized solid solution was produced. From the expanded XRD patterns at $2 \theta$ of $239.5^{\circ}$ and $41^{\circ}$ (Fig. 1(b)), the peak positions moved toward a lower angle when the additional KF increased from 0 to $3.0 \mathrm{~mol} \%$, indicating an enlarged unit cell volume. The enlarged unit cell volume for all ceramics was caused by the substitution of smaller ions by larger ions, such as the replacement of $\mathrm{Bi}^{3+}$ ions $(130 \mathrm{pm})$ or $\mathrm{Na}^{+}$ions $(139 \mathrm{pm})$ by $\mathrm{K}^{+}$ions $(164 \mathrm{pm})$ at the A-sites ${ }^{23}$. On the other hand, the radius of $\mathrm{F}^{-}$is similar to that of $\mathrm{O}^{2-16,17}$. To confirm the dissolution of KF into the lattice of BNT-ST-AN ceramics, the EDX technique was used to analyze the polished and thermally etched surfaces of the BNT-ST-AN ceramics with various KF additions. The results of the EDX mapping of all ceramics are shown in Fig. 2 (a)-(f). $\mathrm{K}^{+}$and $\mathrm{F}^{-}$presented a homogeneous distribution on the surface of the ceramics, and no accumulation of KF was observed. 
(a)
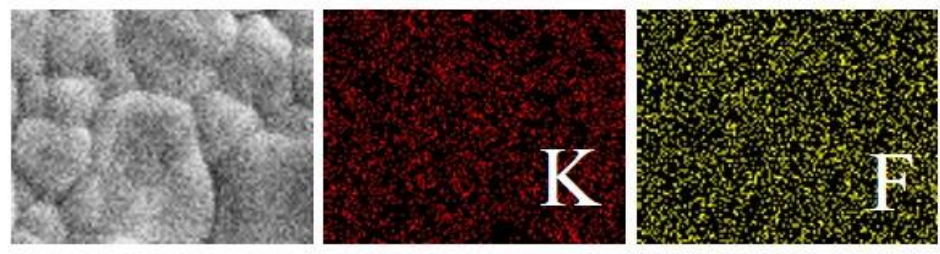

(b)
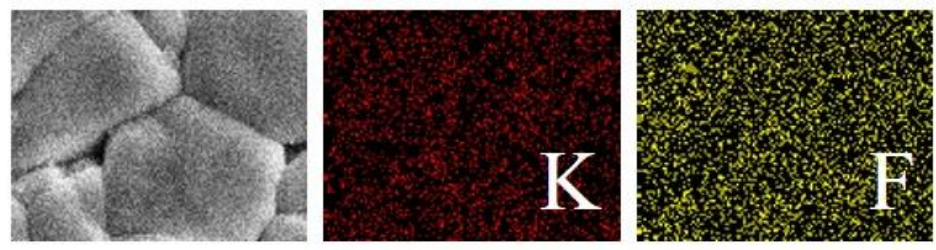

(c)
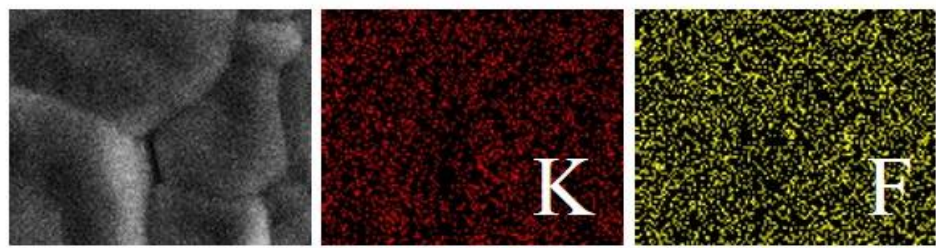

(d)
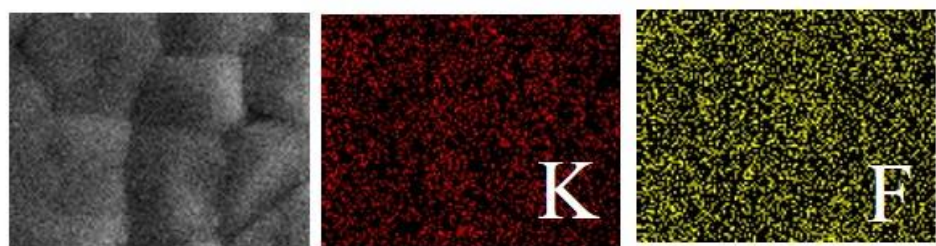

(e)
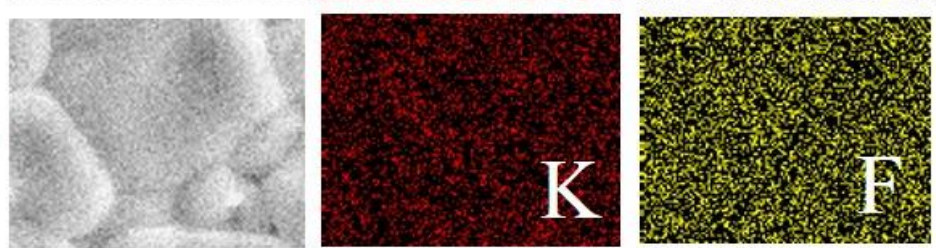

(f)
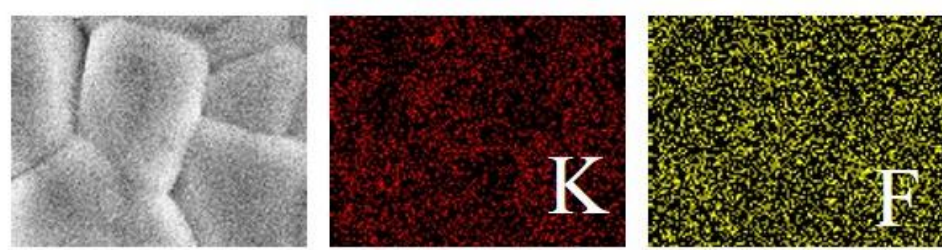

Fig. 2. Typical SEM images and corresponding $K$ and $F$ element maps for the BNT-ST-AN ceramics with KF additions of; (a) 0.5, (b) 1.0, (c) 1.5, (d) 2.0 (e) 2.5 and (f) $3.0 \mathrm{~mol} \%$.

To examine how the phase of BNT-ST-AN ceramics evolves with various KF levels, the Fullprof program was used to analyze the XRD data using Rietveld refinements. During the Rietveld refinement, the sample displacement error, unit cell parameters, and background parameters were varied. The modeling of the crystal structure was based on the rhombohedral 
(space group; R3c), cubic (space group; P4bm) and orthorhombic phases (space group; Amm2) of the perovskite structure that correspond to the crystallography open database ICSD codes 2103295, 1512124 and 1100916, respectively. During the refinement of the X-ray diffraction data of the ceramics, $\mathrm{K}$ and $\mathrm{F}$ were assumed to occupy the A-sites and $\mathrm{O}$-sites of the perovskite structure, respectively. The occupancies of these atoms were fixed according to the nominal stoichiometry for each composition. Furthermore, the refinement used a Chebyshev polynomial function to fit the background and the pseudo-Voigt function to fit peaks 22 and 24 .
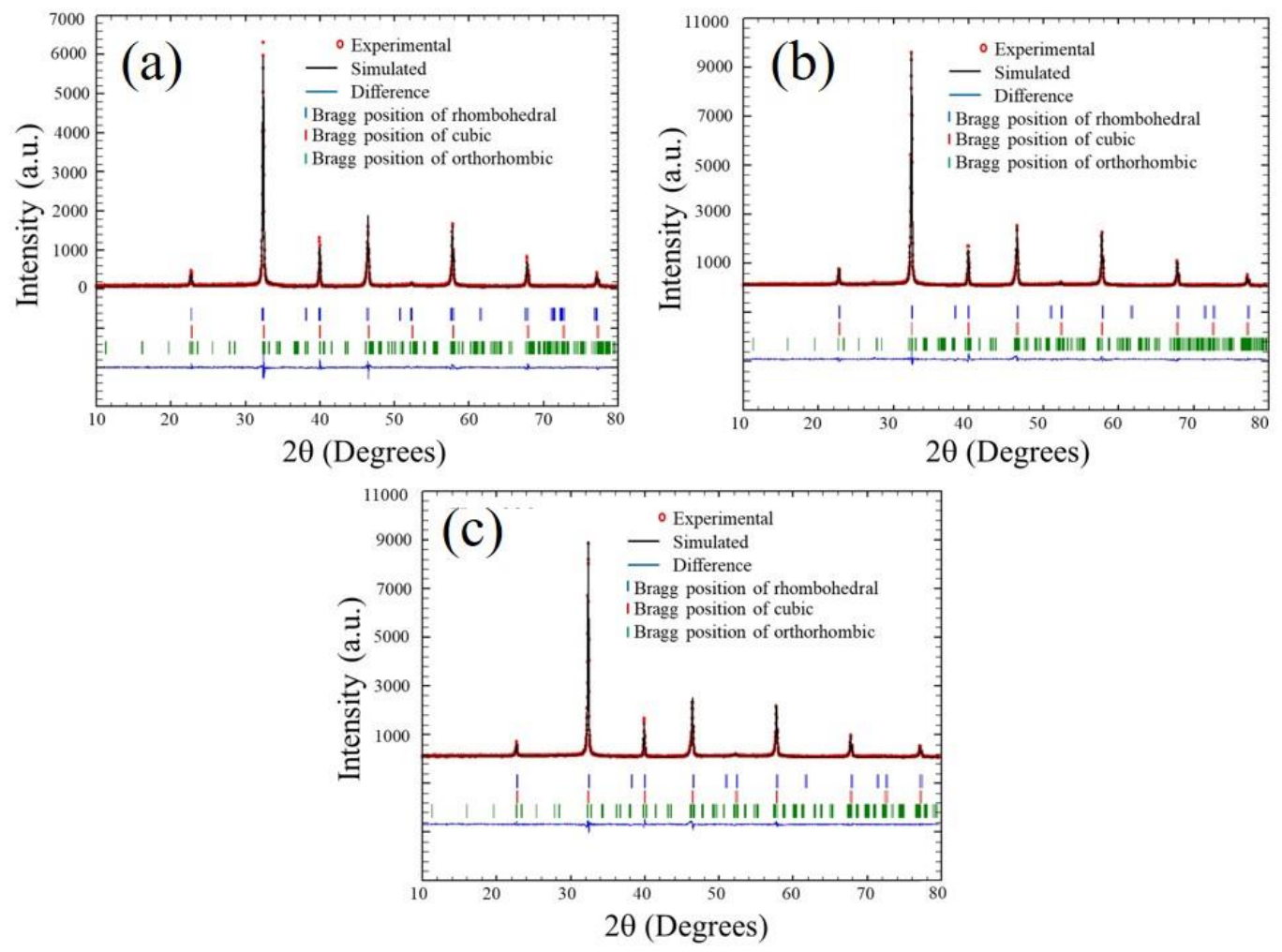

Fig. 3. Rietveld refined XRD patterns of the BNT-ST-AN ceramics at KF additions of (a) 0 , (b) 1.5 , and (c) $3.0 \mathrm{~mol} \%$.

The Rietveld refinement of the X-ray diffraction of the BNT-ST-AN ceramics with KF additions of $0,1.5$ and 3.0 mol\% are shown in Fig. 3 (a)-(c). For the figures, the red circle symbols are experimental data points, and the solid black lines are the simulated patterns. The solid blue line at the bottom represents the difference between the simulated and observed 
patterns, and the vertical bars are the $2 \theta$ positions of all possible Bragg reflections for the selected space group (s). The goodness of fitting indicator and dependability factors were calculated from the Rietveld refinement and are listed in Table 1. The goodness of fit parameters from the fitting procedure are as follows: $\mathrm{R}_{\mathrm{p}} \leq 24 \%, \mathrm{R}_{\mathrm{wp}} \leq 22.7 \%$ and $\chi^{2} \leq 2.73$, which confirmed that the fitting to the phase structural models was in good agreement between the observed and calculated patterns. The phases determined from the fitting of the Rietveld refinement showed mixed rhombohedral $(\mathrm{R})$, cubic $(\mathrm{C})$, and orthorhombic $(\mathrm{O})$ phases in all ceramics. The percentage of each phase of the BNT-ST-AN ceramics with various KF additions is listed in Table 1 . When the KF increased from 0 to $3 \mathrm{~mol} \%$, the percentage of the $\mathrm{R}$ phase decreased from 68 to 14, while the percentage of $\mathrm{C}+\mathrm{O}$ phases increased from 32 to 77 , as listed in Table 1. At a KF addition of $1.5 \mathrm{~mol} \%$, the phase formation showed an equal ratio of $\mathrm{R}$ and $\mathrm{C}+\mathrm{O}$ phases (50:50), which implies that the MPB zone existed in this composition. The lattice parameters of the $\mathrm{R}, \mathrm{C}$ and $\mathrm{O}$ phases of the BNT-ST-AN ceramics with various KF additions are also detailed in Table 1. 
Table 1 Fitting parameters and percentage of each phase for the BNT-ST-AN ceramics with various $\mathrm{KF}$ additions

\begin{tabular}{|c|c|c|c|c|}
\hline $\begin{array}{c}\text { KF addition } \\
(\mathrm{mol} \%)\end{array}$ & Refine parameters & Phase structures & $\begin{array}{l}\text { Lattice parameters } \\
(\AA)\end{array}$ & The percentage of phase \\
\hline \multirow[t]{3}{*}{0} & \multirow{3}{*}{$\begin{array}{l}\chi^{2}=1.31 \\
R_{\mathrm{p}}=22.1 \% \\
R_{\mathrm{wp}}=19.3 \% \\
R_{\exp }=16.87 \%\end{array}$} & $R 3 c: H$ & $\begin{array}{c}a=5.5482 \\
c=13.5289\end{array}$ & 68 \\
\hline & & $P m-3 m$ & $a=\mathrm{b}=\mathrm{c}=3.9062$ & 24 \\
\hline & & Pbcm & $\begin{array}{c}a=5.5081 \\
\mathrm{~b}=5.4990 \\
c=15.7563\end{array}$ & 8 \\
\hline \multirow[t]{3}{*}{0.5} & \multirow{3}{*}{$\begin{array}{l}\chi^{2}=1.58 \\
R_{\mathrm{p}}=19.4 \% \\
R_{\mathrm{wp}}=17.9 \% \\
R_{\exp }=14.26 \%\end{array}$} & $R 3 c: H$ & $\begin{array}{l}a=5.5248 \\
c=13.5328\end{array}$ & 53 \\
\hline & & $P m-3 m$ & $a=\mathrm{b}=\mathrm{c}=3.9118$ & 39 \\
\hline & & Pbcm & $\begin{array}{l}a=5.5938 \\
\mathrm{~b}=5.5200 \\
c=15.6703\end{array}$ & 8 \\
\hline \multirow[t]{3}{*}{1.0} & \multirow{3}{*}{$\begin{array}{l}\chi^{2}=2.73 \\
R_{\mathrm{p}}=22.9 \% \\
R_{\mathrm{wp}}=23.8 \% \\
R_{\exp }=14.41 \%\end{array}$} & $R 3 c: H$ & $\begin{array}{l}a=5.5210 \\
c=13.5294\end{array}$ & 52 \\
\hline & & $P m-3 m$ & $a=\mathrm{b}=\mathrm{c}=3.9087$ & 41 \\
\hline & & $\mathrm{Pbcm}$ & $\begin{array}{c}a=5.6209 \\
\mathrm{~b}=5.4774 \\
c=15.7619\end{array}$ & 7 \\
\hline \multirow[t]{3}{*}{1.5} & \multirow{3}{*}{$\begin{array}{l}\chi^{2}=1.40 \\
R_{\mathrm{p}}=17.9 \% \\
R_{\mathrm{wp}}=16.4 \% \\
R_{\exp }=13.87 \%\end{array}$} & $R 3 c: H$ & $\begin{array}{l}a=5.5235 \\
c=13.5321\end{array}$ & 50 \\
\hline & & $P m-3 m$ & $a=\mathrm{b}=\mathrm{c}=3.9108$ & 43 \\
\hline & & Pbcm & $\begin{array}{c}a=5.5952 \\
\mathrm{~b}=5.5222 \\
c=15.74123\end{array}$ & 7 \\
\hline \multirow[t]{3}{*}{2.0} & \multirow{3}{*}{$\begin{array}{l}\chi^{2}=2.42 \\
R_{\mathrm{p}}=24.1 \% \\
R_{\mathrm{wp}}=22.7 \% \\
R_{\exp }=14.62 \%\end{array}$} & $R 3 c: H$ & $\begin{array}{l}a=5.5229 \\
c=13.5329\end{array}$ & 39 \\
\hline & & $P m-3 m$ & $a=\mathrm{b}=\mathrm{c}=3.9063$ & 49 \\
\hline & & Pbcm & $\begin{array}{c}a=5.5616 \\
\mathrm{~b}=5.5370 \\
c=15.6795\end{array}$ & 12 \\
\hline \multirow[t]{3}{*}{2.5} & \multirow{3}{*}{$\begin{array}{l}\chi^{2}=1.35 \\
R_{\mathrm{p}}=17.8 \% \\
R_{\mathrm{wp}}=16.3 \% \\
R_{\exp }=14.04 \%\end{array}$} & $R 3 c: H$ & $\begin{array}{c}a=5.5246 \\
c=13.5375\end{array}$ & 28 \\
\hline & & $P m-3 m$ & $a=\mathrm{b}=\mathrm{c}=3.9181$ & 56 \\
\hline & & Pbcm & $\begin{array}{c}a=5.5827 \\
\mathrm{~b}=5.5319 \\
c=15.7505\end{array}$ & 16 \\
\hline \multirow[t]{3}{*}{3.0} & \multirow{3}{*}{$\begin{array}{l}\chi^{2}=1.62 \\
R_{\mathrm{p}}=19.9 \% \\
R_{\mathrm{wp}}=18.4 \% \\
R_{\exp }=14.49 \%\end{array}$} & $R 3 c: H$ & $\begin{array}{c}a=5.5272 \\
c=13.5403\end{array}$ & 14 \\
\hline & & $P m-3 m$ & $a=\mathrm{b}=\mathrm{c}=3.9119$ & 65 \\
\hline & & Pbcm & $\begin{array}{l}a=5.5604 \\
\mathrm{~b}=5.5360 \\
c=15.736\end{array}$ & 21 \\
\hline
\end{tabular}



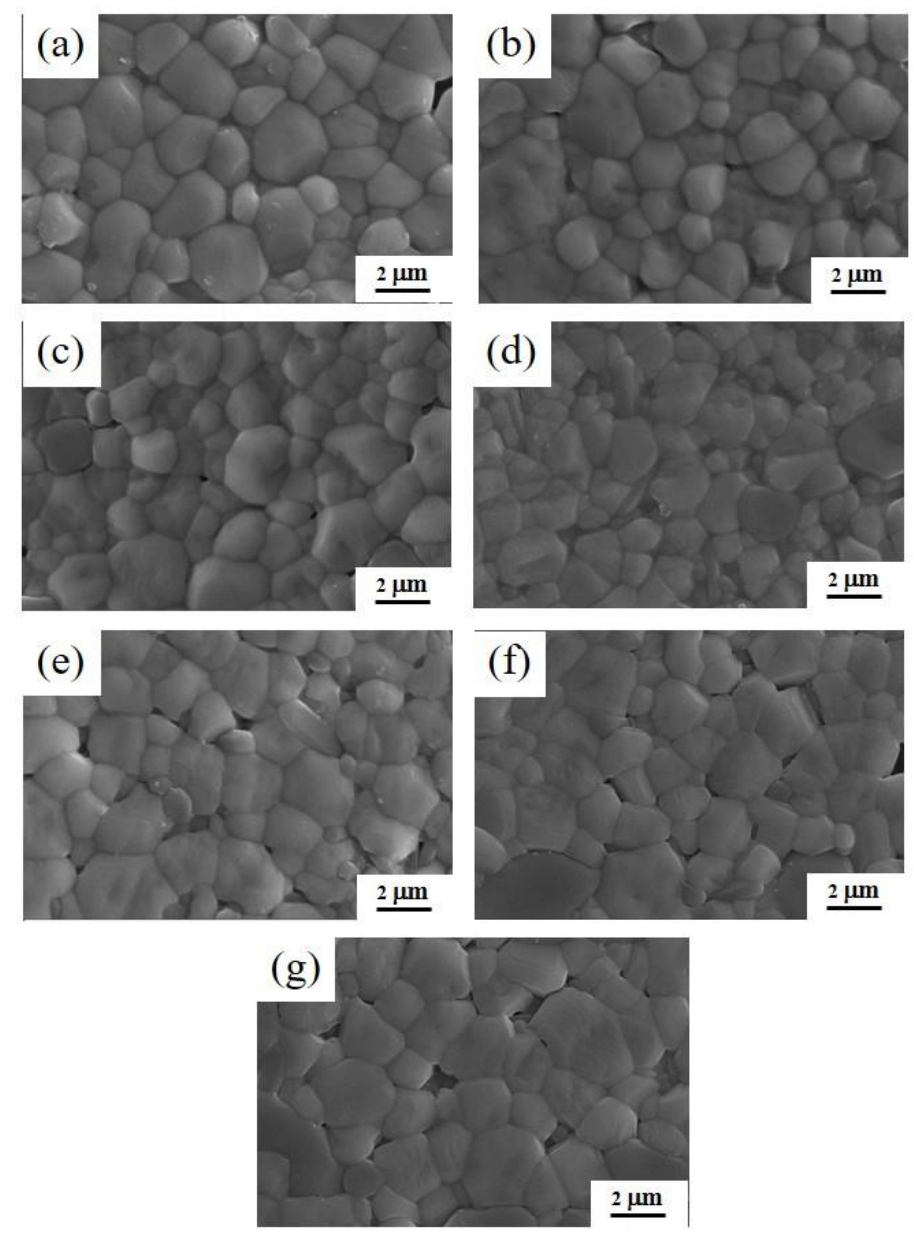

Fig. 4 SEM images of the polished and thermally etched surfaces of the BNT-ST-AN ceramics with KF additions of (a) 0, (b) 0.5, (c) 1.0, (d) 1.5, (e) 2.0, (f) 2.5 and (g) $3.0 \mathrm{~mol} \%$.

The surface morphologies of the polished and thermally etched BNT-ST-AN ceramics with various KF additions are shown in Fig. 4 (a)-(g). The SEM images showed polygonshaped grains for all of the ceramics. For a small amount of KF addition between 0 and 1.5 mol\%, the ceramics exhibited a dense grain morphology, and the average grain size greatly reduced from 2.07 to $1.15 \mu \mathrm{m}$ with increasing $\mathrm{KF}$ addition from 0 to $1.5 \mathrm{~mol} \%$. The decrease in grain size of the ceramics at $\mathrm{KF}$ addition from 0 to 1.5 mol\% can be explained by the reduction in oxygen vacancies. Normally, $\mathrm{Na}^{+}$cations volatilize during the high-temperature sintering process, as demonstrated in Eq. (1). The addition of KF into BNT-ST-AN ceramics can suppress the loss from such volatilization. The $\mathrm{KF}$ addition generated $\mathrm{K}^{+}$and $\mathrm{F}^{-}$ions, which 
diffused into the BNT-ST-AN crystal lattice. The substitution of $\mathrm{K}^{+}$could compensate for the loss of $\mathrm{Na}^{+}$and not create vacancies because it is an isovalent substitution, as seen in Eq. 3 . The substitution of the $\mathrm{F}-$ anion for $\mathrm{O}^{2-}$ (point defect $F_{O}^{\bullet}$ ) can reduce the formation of oxygen vacancies (Eq. (4)) and led to inhibition of the train growth during sintering ${ }^{16,17}$.

$$
\begin{aligned}
& 2 K F \stackrel{N a_{2} O}{\longrightarrow} 2 K_{N a}^{x}+F_{O}^{\bullet}+F_{i}^{\prime \prime} \text { or } 2 K F \stackrel{N a_{2} O}{\longrightarrow} 2 K_{N a}^{x}+F_{O}^{\bullet}+2 e^{\prime} \\
& F_{F}^{x}+V_{O}^{*}+2 e^{\prime} \rightarrow F_{O}^{\bullet}+e^{\prime}
\end{aligned}
$$

When the KF addition increased from 1.5 to $3.0 \mathrm{~mol} \%$, the grain size slightly increased from 1.15 to $1.85 \mu \mathrm{m}$ (Table 2), and a porous structure was formed. The grains tended to grow with increasing $\mathrm{KF}$ addition from 1.5 to $3.0 \mathrm{~mol} \%$, which can be attributed to excessive amount of $\mathrm{KF}$ addition, promoting more liquid phase which stimulated mass transfer and favored grain growth. The average grain size were listed in table 2 . The smallest grain size was obtained from the BNT-ST-AN ceramics with a KF addition of $0.15 \mathrm{~mol} \%$, which has a positive effect on the reduction of the $\mathrm{P}_{\mathrm{r}}$ value ${ }^{11}$.

The measured densities of the BNT-ST-AN ceramics with various KF additions are listed in Table 2. The measured density increased from 5.42 to $5.65 \mathrm{~g} / \mathrm{cm}^{3}$ when KF increased from 0.0 to $1.5 \mathrm{~mol} \%$ (Table 2). As KF increased between 1.5 and $3.0 \mathrm{~mol} \%$, the measured density slightly decreased (Table 2), which was affected by the pores at the grain boundaries. The measured density of all the ceramics corresponded with the SEM results. 

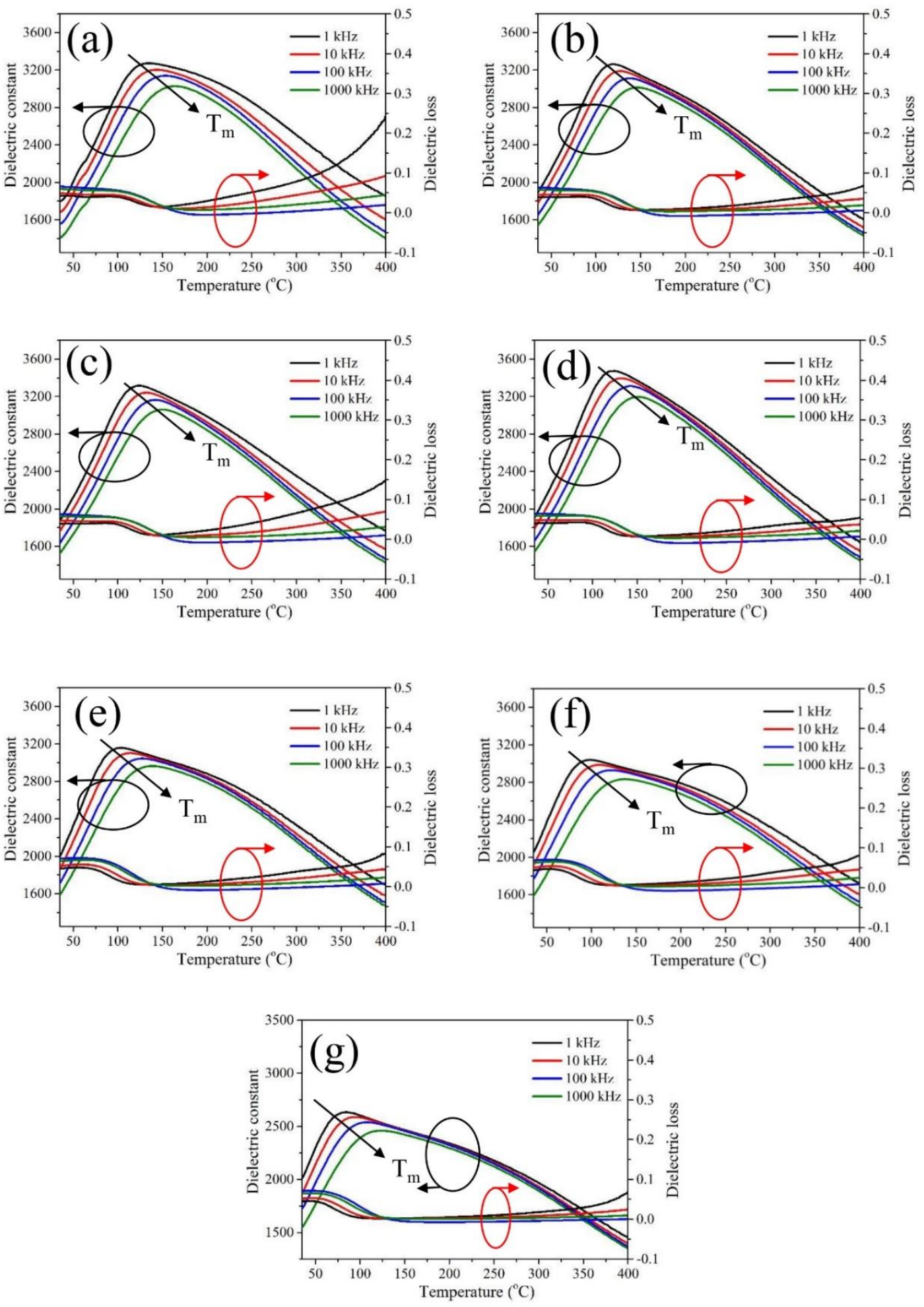

Fig. 5. Temperature-dependent and frequency-dependent permittivity of the BNT-ST-AN ceramics with KF additions of (a) 0, (b) 0.5, (c) 1.0, (d) 1.5, (e) 2.0 (f) 2.5 and (g) $3.0 \mathrm{~mol} \%$. 


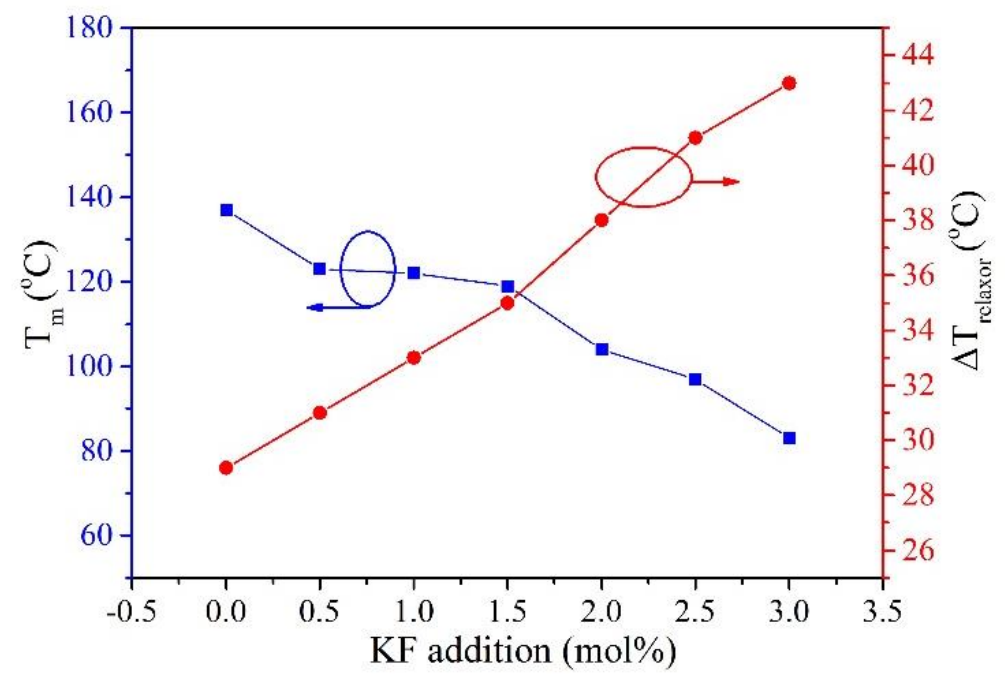

Fig. 6. $\mathrm{T}_{\mathrm{m}}$ and $\Delta \mathrm{T}_{\text {relaxor }}$ of BNT-ST-AN ceramics with various $\mathrm{KF}$ additions.

The temperature- $\left(25-400^{\circ} \mathrm{C}\right)$ and frequency- $(1-1000 \mathrm{kHz})$ dependent dielectric constant $(\varepsilon)$ and loss factor $(\tan \delta)$ of all unpoled BNT-ST-AN ceramics with various KF additions are presented in Fig. 5 (a)-(g). Generally, BNT-based lead-free relaxor ferroelectrics exhibit two dielectric anomalies ${ }^{25}$. The first dielectric anomaly is associated with a transformation from ferroelectric to relaxor-ferroelectric, which indicates the thermal evolution of the low-temperature polar nanoregions R3c and P4bm (LT-PNRs) ${ }^{25}$. The second dielectric anomaly is associated with the temperature of maximal permittivity $\left(\mathrm{T}_{\mathrm{m}}\right)$, with contributions from the R3c-P4bm transition and the thermal evolution of high-temperature P4bm polar nanoregions (HT-PNRs) ${ }^{25-27}$. In this work, the dielectric anomalies of all ceramics showed overlap of the two anomalies, and the broad peaks may be caused by diffuse dielectric anomalies, which was similar to other BNT-ST-based relaxor ferroelectrics ${ }^{13,14}$. As KF addition increased, the dielectric anomalies became more diffuse, and the dielectric anomalies at $\mathrm{T}_{\mathrm{m}}$ continuously shifted to lower temperatures (Fig. 5 (a)-(g)), which was characteristic of relaxor ferroelectric behavior. Moreover, a parameter to explain the relaxor behavior (in the frequency range from $1 \mathrm{kHz}$ to $1000 \mathrm{kHz}$ ) can be assigned using the following equation (5) ${ }^{28}$ :

$$
\Delta T_{\text {relaxor }}=T_{m_{(1000 \mathrm{kHz})}}-T_{m_{(1 \mathrm{kHz})}}
$$


The calculated $\Delta T_{\text {relaxor }}$ values are shown in Fig. 6. It was found that $\Delta T_{\text {relaxor }}$ increased when KF increased, which indicated that the degree of relaxor behavior continuously increased. Commonly, the relaxor behavior of BNT-based ceramics develops from multiple cation ions $\left(\mathrm{Na}^{+}, \mathrm{Bi}^{3+}\right)$ at equal crystallographic sites that possess similar radii but different charges ${ }^{23}$. When $\mathrm{KF}$ increased, the $\mathrm{K}^{+}$diffused into the $\mathrm{Na} / \mathrm{Bi}$ sublattice, which led to an increase in cation disorder. Therefore, the stronger relaxor behavior in this work resulted from the increased cation disorder because of isolated clusters of polar nanoregions (PNRs) with only weak coupling between the neighboring clusters, leading to a slightly longrange ferroelectric order ${ }^{29,30}$. The $\mathrm{T}_{\mathrm{m}}$ at $1 \mathrm{kHz}$ decreased from $137^{\circ} \mathrm{C}$ to $24^{\circ} \mathrm{C}$ when adding $\mathrm{KF}$, as presented in Fig. 6. An operation temperature below $\mathrm{T}_{\mathrm{m}}$ can avoid early polarization saturation, which is good for ceramic energy storage properties ${ }^{13,14}$.

To consider the dielectric constant at room temperature $\left(\varepsilon_{\mathrm{r}}\right)$ and at $\mathrm{T}_{\mathrm{m}}\left(\varepsilon_{\mathrm{m}}\right)$, it was observed that the $\varepsilon_{\mathrm{r}}$ values tended to rise when KF increased, as seen in Table 2 . The $\varepsilon_{\mathrm{m}}$ values increased from 3261 to 3473 with increasing $\mathrm{KF}$ addition from 0.0 to $1.5 \mathrm{~mol} \%$ and then dropped (Table 2). The $\tan \delta$ values at room temperature $\left(\tan \delta_{\mathrm{r}}\right)$ and at $\mathrm{T}_{\mathrm{m}}\left(\tan \delta_{\mathrm{m}}\right)$ of all ceramics were in the range of $0.038-0.046$ and $0.011-0.017$, respectively, as listed in Table 2 . The dielectric property results corresponded to the morphology and density results.

Table 2. Average grain size, density, and dielectric properties of BNT-ST-AN ceramics with various $\mathrm{KF}$ additions

\begin{tabular}{ccccccc}
\hline $\begin{array}{c}\text { KF addition } \\
(\mathrm{mol} \%)\end{array}$ & $\begin{array}{c}\text { Average } \\
\text { grain size }(\mu \mathrm{m})\end{array}$ & $\begin{array}{c}\text { Density } \\
\left(\mathrm{g} / \mathrm{cm}^{3}\right)\end{array}$ & $\varepsilon_{\mathrm{r}}$ & $\tan \delta_{\mathrm{r}}$ & $\varepsilon_{\mathrm{m}}$ & $\tan \delta_{\mathrm{m}}$ \\
\hline 0 & $2.07 \pm 0.41$ & 5.42 & 1769 & 0.038 & 3261 & 0.017 \\
0.5 & $1.71 \pm 0.38$ & 5.49 & 1886 & 0.040 & 3275 & 0.011 \\
1.0 & $1.34 \pm 0.46$ & 5.57 & 1870 & 0.041 & 3316 & 0.012 \\
1.5 & $1.15 \pm 0.34$ & 5.67 & 1908 & 0.040 & 3473 & 0.014 \\
2.0 & $1.48 \pm 0.44$ & 5.56 & 1998 & 0.044 & 2632 & 0.010 \\
2.5 & $1.72 \pm 0.46$ & 5.44 & 2017 & 0.046 & 3039 & 0.015 \\
3.0 & $1.85 \pm 0.52$ & 5.35 & 1943 & 0.046 & 3147 & 0.012 \\
\hline
\end{tabular}


Room-temperature P-E loops of BNT-ST-AN ceramics with various KF levels, measured in an electric field of $100 \mathrm{kV}$, are displayed in Fig. 7(a). The P-E loops of all ceramics showed slim loops, which indicated excellent relaxor ferroelectric behavior ${ }^{13,14}$. Fig. 7 (b) shows the unipolar P-E loops of all ceramics measured in an electric field of $100 \mathrm{kV}$. It was observed that the unipolar P-E loops became thin and inclined with increasing KF addition, indicating hardening of the ferroelectric strength, and a higher nonergodic relaxor phase was produced ${ }^{13,14}$. For the remnant polarization $\left(\mathrm{P}_{\mathrm{r}}\right)$, the $\mathrm{P}_{\mathrm{r}}$ values decreased from 4.37 to 1.57 $\mu \mathrm{C} / \mathrm{cm}^{2}$ when the $\mathrm{KF}$ addition increased from 0 to $1.5 \mathrm{~mol} \%$ and then slightly increased, as shown in Fig. 7 (c). The lowest $\mathrm{P}_{\mathrm{r}}$ value of $1.57 \mu \mathrm{C} / \mathrm{cm}^{2}$ was obtained from the sample with KF at $1.5 \mathrm{~mol} \%$ (Fig. 7 (c)). The maximum polarization $\left(\mathrm{P}_{\mathrm{m}}\right)$ continuously decreased when 0 to $3.0 \mathrm{~mol} \% \mathrm{KF}$ was added, as shown in Fig. 7 (c). When $1.5 \mathrm{~mol} \% \mathrm{KF}$ was added, the ceramic showed the lowest remnant polarization $\left(\mathrm{P}_{\mathrm{r}}\right)$ and a large maximum polarization $\left(\mathrm{P}_{\mathrm{m}}\right)$ due to the phase formation in this composition being in the MPB zone and it has the smallest grain size. From the results above, the reduction of $\mathrm{P}_{\mathrm{r}}$ and $\mathrm{P}_{\mathrm{m}}$ can be attributed to the long-range ferroelectric decomposition as more PNRs are formed and stronger relaxor ferroelectric behavior due to the addition of $\mathrm{KF}^{13,14}$. These changes in $\mathrm{P}_{\mathrm{r}}$ and $\mathrm{P}_{\mathrm{m}}$ in the hysteresis affected the energy storage density and efficiency. For capacitors, electrical energy is stored in dielectric materials when the capacitors are charged by an electric field. The energy density is calculated by integrating the effective area between the polarization axis and the discharging curve of the polarization-electric field (P-E) loops ${ }^{31}$. The energy storage density and the energy storage efficiency $(\eta)$ are calculated from the following equations:

$$
\begin{aligned}
& W_{\text {rec }}=\int_{P_{r}}^{P_{m}} E d p \\
& W_{t}=\int_{0}^{P_{m}} E d p \\
& \eta=\frac{w_{r e c}}{w_{t}}
\end{aligned}
$$


In equations (6), (7) and (8), $\mathrm{P}_{\mathrm{r}}, \mathrm{P}_{\mathrm{m}}, \mathrm{E}, \mathrm{W}_{\mathrm{rec}}$ and $\mathrm{W}_{\mathrm{t}}$ are the remnant polarization, the maximum polarization, the electric field, recoverable energy storage density and the total energy storage density, respectively. The calculated results for $\mathrm{W}_{\mathrm{rec}}, \mathrm{W}_{\mathrm{t}}$ and $\eta$ are shown in Fig. 7 (d). It was observed that the $\mathrm{W}_{\text {rec }}$ and $\eta$ values continuously increased from 1.46 to 1.60 $\mathrm{J} / \mathrm{cm}^{3}$ and 71.2 to $85.83 \%$ when $\mathrm{KF}$ was added up to $1.5 \mathrm{~mol} \%$ and then dropped in value (Fig. 7 (d)). The deterioration in $\mathrm{W}_{\text {rec }}$ and $\eta$ can be indicative of energy loss when increasing $\mathrm{KF}$ over $1.5 \mathrm{~mol} \%$. The $\mathrm{W}_{\mathrm{t}}$ values tend to decrease when increasing $\mathrm{KF}$ from 0 to $1.5 \mathrm{~mol} \%$, which affects the $W_{\text {rec }}$ and $\eta$ values.
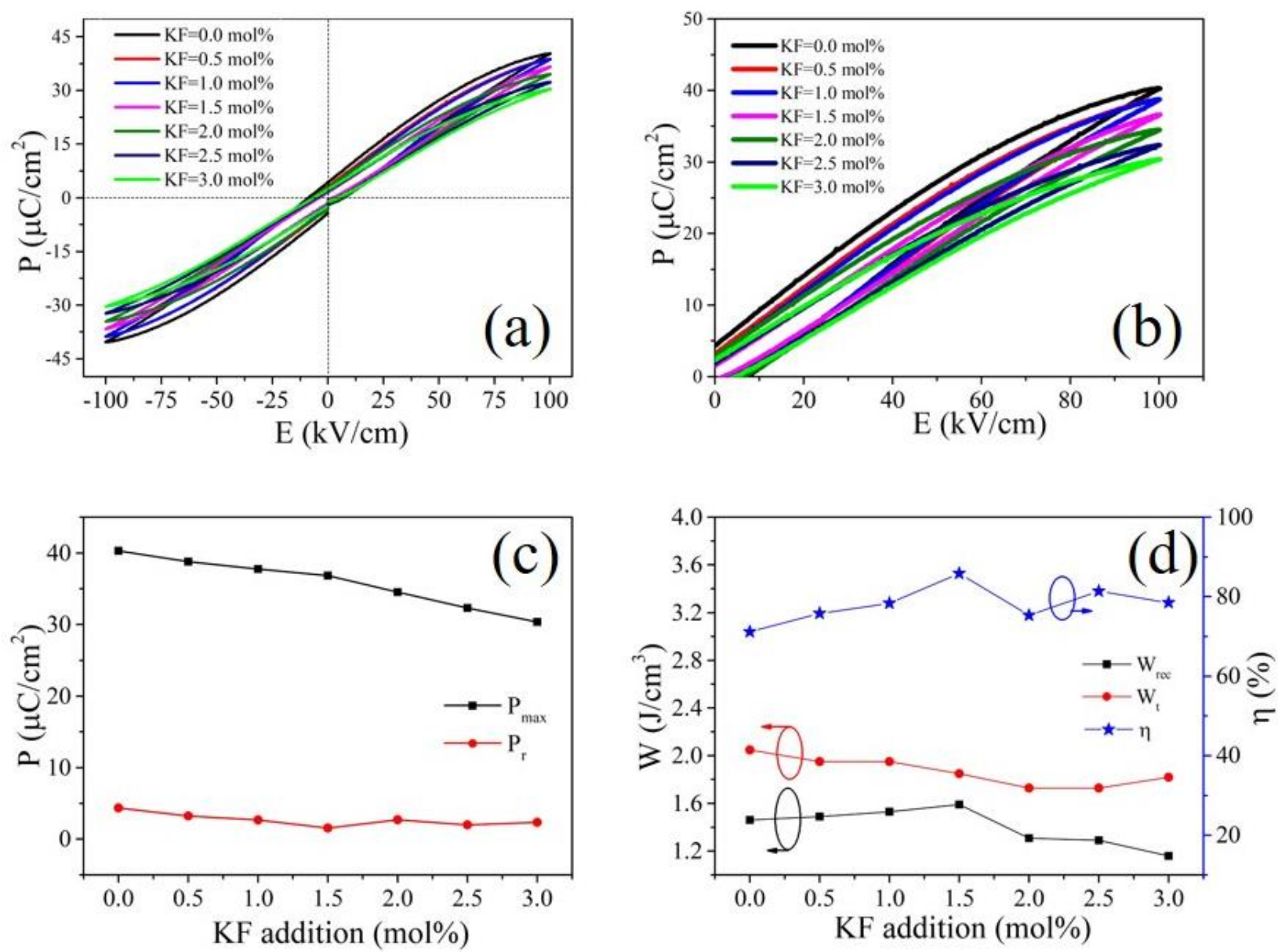

Fig. 7 Room temperature (a) P-E hysteresis loops, (b) unipolar P-E loops, (c) $\mathrm{P}_{\mathrm{r}}, \mathrm{P}_{\mathrm{m}}$, values and (d) energy-storage properties of BNT-ST-AN ceramics with various KF additions measured at $100 \mathrm{kV} / \mathrm{cm}$. 

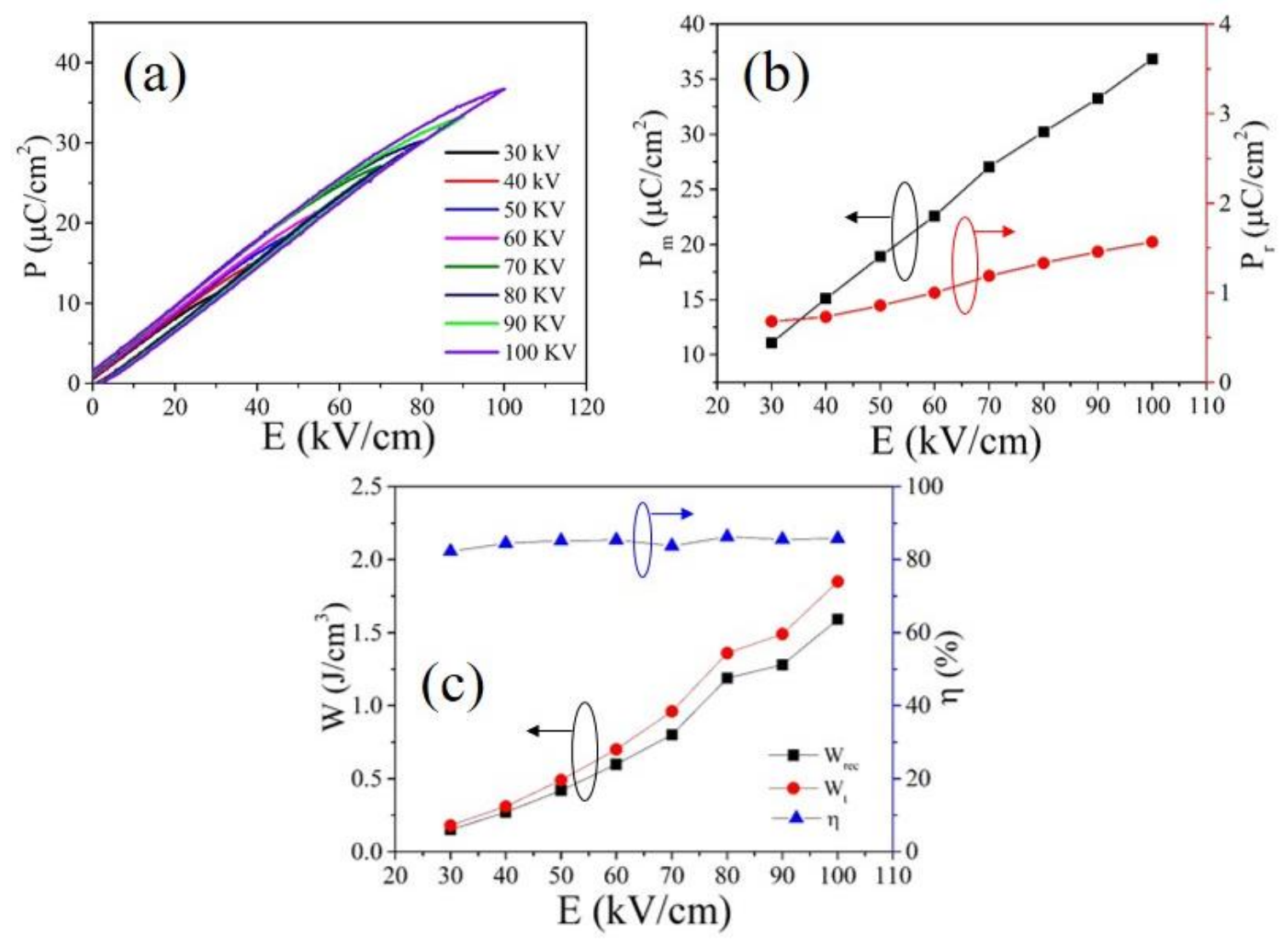

Fig. 8 Room temperature of (a) unipolar P-E loops, (b) $\mathrm{P}_{\mathrm{r}}, \mathrm{P}_{\mathrm{m}}$, values and (c) energy-storage properties of BNT-ST-AN ceramics at KF additions of 1.5 mol\% measured at $30-100 \mathrm{kV} / \mathrm{cm}$.

Fig. 8 (a) shows the unipolar P-E loops under applied electric fields between 30 and $100 \mathrm{kV}$ of BNT-ST-AN ceramics with KF at $1.5 \mathrm{~mol} \%$. The unipolar P-E loops of all ceramics showed elongated loops with increasing electric field. The $\mathrm{P}_{\mathrm{r}}$ and $\mathrm{P}_{\mathrm{m}}$ values continuously increased from 0.68 to $1.58 \mu \mathrm{C} / \mathrm{cm}^{2}$ and 11.09 to $36.85 \mu \mathrm{C} / \mathrm{cm}^{2}$, respectively, when the electric field increased from 30 to $100 \mathrm{kV} / \mathrm{cm}$, as shown in Fig. 8 (b). The $\mathrm{W}_{\text {rec }}$ and $\mathrm{W}_{\mathrm{t}}$ values under different applied electric fields are summarized in Fig. 8 (c). Both $\mathrm{W}_{\text {rec }}$ and $\mathrm{W}_{\mathrm{t}}$ values enhanced from 0.15 to $1.60 \mathrm{~J} / \mathrm{cm}^{3}$ and 0.18 to $1.85 \mathrm{~J} / \mathrm{cm}^{3}$, respectively, when increasing the applied electric field between 30 and $100 \mathrm{kV} / \mathrm{cm}$, which can be due to the increase in $P_{m}$. The $\eta$ values are nearly the same for all electric field strengths, as seen in Fig. 8 (c), which indicates the stability of the stored energy for the applied electric field ${ }^{32}$. The addition of 1.5 mol\% KF to 
BNT-ST-AN ceramics can hopefully be applied in energy-storage systems due to the ceramics having a large polarization, which ensures a high energy storage density at low electric field strength.
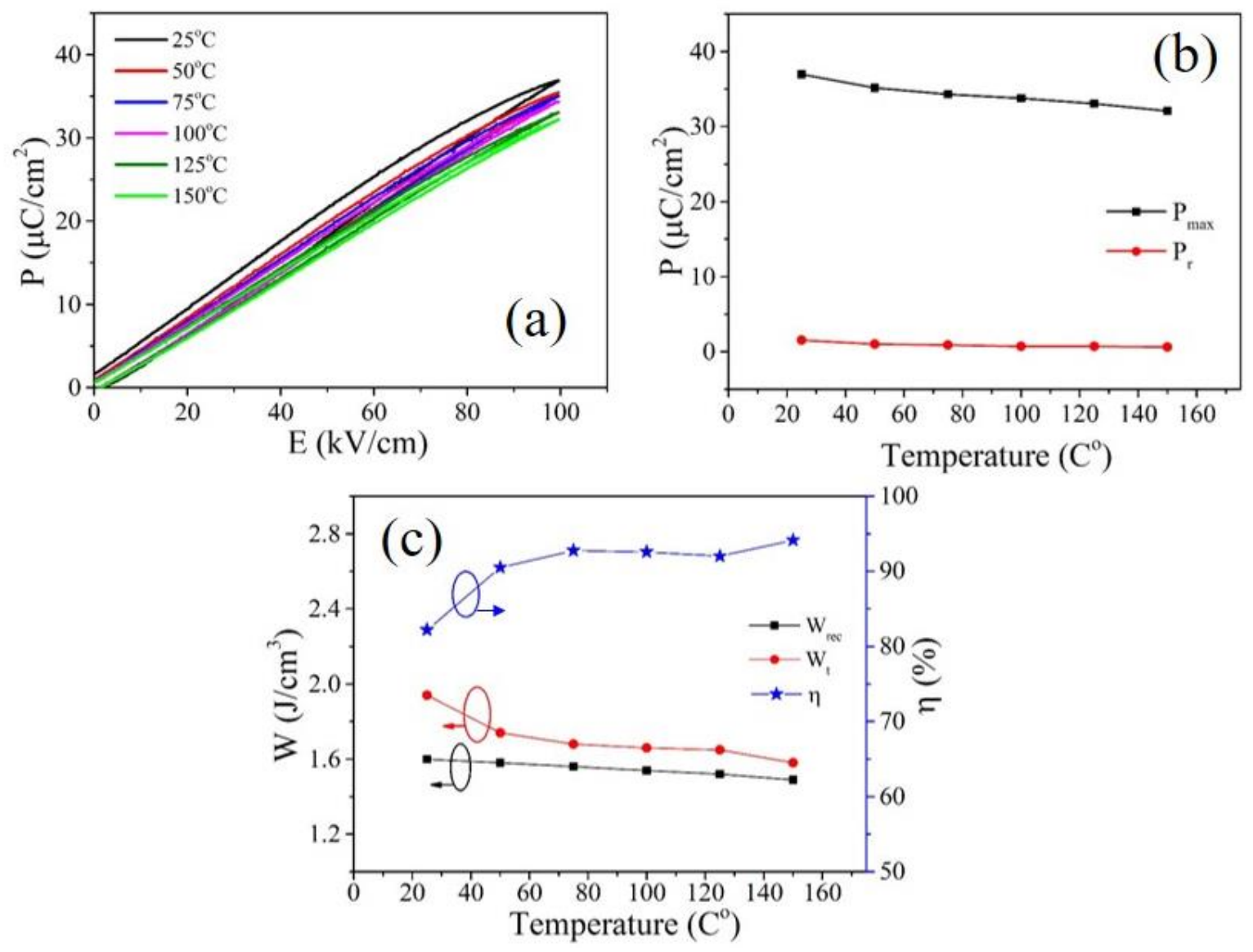

Fig. 9 (a) Unipolar P-E loops, (b) $\mathrm{P}_{\mathrm{r}}, \mathrm{P}_{\mathrm{m}}$, values and (c) energy-storage properties of BNT-ST$\mathrm{AN}$ ceramics at a $\mathrm{KF}$ addition of $1.5 \mathrm{~mol} \%$ measured at $100 \mathrm{kV} / \mathrm{cm}$ at various temperatures.

Thermal stability is an essential evaluation for energy storage materials in terms of the application prospects of harsh temperature conditions $[14,33]$. To determine the thermal stability of the energy storage properties, unipolar P-E loops of the BNT-ST-AN ceramics with $\mathrm{KF}$ at $1.5 \mathrm{~mol} \%$, measured at an applied electric potential of $100 \mathrm{kV}$, through the temperature range of $25^{\circ} \mathrm{C}-150^{\circ} \mathrm{C}$ are plotted in Fig. 9 (a). It was found that the unipolar P-E loops at all temperatures showed great temperature stability when the temperature increased, which 
indicated a broad diffuse phase transformation of the nonergodic relaxor phase and ergodic relaxor state coexisting in a wide temperature range, as seen in the dielectric anomalies (Fig. 5). The $P_{r}$ values were almost temperature independent, and the $P_{m}$ values slightly decreased when the temperature increased from 25 to $150^{\circ} \mathrm{C}$, as seen in Fig. 9 (b). For the results of the energy storage property at various temperatures, the $\mathrm{W}_{\text {rec }}$ and $\mathrm{W}_{\mathrm{t}}$ values slightly decreased while the $\eta$ values increased, as shown in Fig. 9(c). This result robustly confirmed the excellent stability of the thermal properties of relaxor ferroelectric ceramics ${ }^{14}$. To compare energy storage properties with BNT lead-free materials ${ }^{14,23,32,34-37}$, it was observed that BNT-ST-AN ceramics with a KF of $1.5 \mathrm{~mol} \%$ in this work exhibited an ultrahigh energy storage density under a low applied electric field while maintaining a high efficiency, which makes them a very promising dielectric material for energy storage applications.

\section{Conclusions}

The high energy storage performance of $\left(0.722\left(\mathrm{Bi}_{0.5} \mathrm{Na}_{0.5} \mathrm{TiO}_{3}\right)-0.228\left(\mathrm{SrTiO}_{3}\right)-\right.$ $0.05\left(\mathrm{AgNbO}_{3}\right)$ (BNT-ST-AN) ceramics was successfully prepared by the solid-state combustion technique using low firing temperatures and forming the appropriate quantity with an increased liquid phase and oxygen vacancies by adding KF. All ceramics showed coexisting multi rhombohedral $(\mathrm{R})+$ cubic $(\mathrm{C})+$ orthorhombic $(\mathrm{O})$ phases. A morphotropic phase boundary (MPB) was formed with a 50(R):50(C+O) phase percentage, which introduced the lowest remnant polarization $\left(\mathrm{P}_{\mathrm{r}}\right)$ and large maximum polarization $\left(\mathrm{P}_{\mathrm{m}}\right)$ obtained from BNT-ST-AN ceramics with $1.5 \mathrm{~mol} \% \mathrm{KF}$. The $1.5 \mathrm{~mol} \% \mathrm{KF}$ ceramic with the MPB composition also exhibited the smallest grain size, the highest density $\left(5.67 \mathrm{~g} / \mathrm{cm}^{3}\right)$, the highest maximum dielectric constant $\left(\varepsilon_{\mathrm{m}}=3473\right)$ and the highest recoverable energy storage density $\left(\mathrm{W}_{\text {rec }}=1.60\right.$ $\mathrm{J} / \mathrm{cm}^{3}$ ) under a low electric field of $100 \mathrm{kV} / \mathrm{cm}$. Moreover, the ceramics with an energy storage density at the MPB composition exhibited excellent temperature $\left(25-150^{\circ} \mathrm{C}\right)$ stability. Therefore, BNT-ST-AN ceramics with added $1.5 \mathrm{~mol} \% \mathrm{KF}$ are very promising for lead-free 
dielectric materials for applications such as high energy-storage systems with a wide temperature range.

\section{ACKNOWLEDGEMENTS}

The authors wish to thank the Department of Physics, Faculty of Science, Naresuan University and the Department of Physics and General Science, Faculty of Science and Technology, Chiang Mai Rajabhat University for their supporting facilities. Thanks, are also given to Asst. Prof. Dr. Kyle V. Lopin for his help in editing the manuscript.

\section{FUNDING}

This work was financially supported by The National Science, Research and Innovation Fund (NSRF) through Naresuan University (R2564B001) and Office of Ministry of Higher Education, Science, Research and Innovation (MHESI) of Thailand, Grant No. RGNS 63-200.

\section{References}

1. Barath, J. G. N., Husev, O. \& Manonmani, N. Overview of energy storage technologies for renewable energy. J. Innov. Sci. Eng. Tech. 2, 749-754 (2015).

2. Yang, L., Kong, X., Li, F., Hao, H., Cheng, Z., Liu H, Li, J. F. \& Zhang, S. Perovskite lead-free dielectrics for energy storage applications. Prog. Mate. Sci. 102, 72-108 (2019).

3. Fayegh, S. K. \& Rosen, M. A. A review of energy storage types, applications and recent developments. J. Energy Storage. 27, 101047 (2020).

4 Wang, Y., Zhou, X., Chen, Q., Chu, B. J. \& Zhang, Q. M. Recent development of high energy density polymers for dielectric capacitors. IEEE Trans. Dielectr. Electr. Insul. 17, 1037-1041 (2010).

5. Li, W. B., Zhou, D. \& Pang, L.X., Enhanced energy storage density by introducing defect dipoles in lead-free relaxor ferroelectric $\mathrm{BaTiO}_{3}$-based ceramics. Appl. Phys. Lett. 110, 132902 (2017).

6. Gao, F., Dong, X., Mao, C., Cao, F., Wang, G. \& Zhang, S.T. c/a ratio-dependent energystorage density in $(0.9-\mathrm{x}) \mathrm{Bi}_{0.5} \mathrm{Na}_{0.5} \mathrm{TiO}_{3}-\mathrm{xBaTiO}_{3}-0.1 \mathrm{~K}_{0.5} \mathrm{Na}_{0.5} \mathrm{NbO}_{3}$ ceramics. J. Am. Ceram. Soc. 94, 4162-4164 (2011).

7. Yan, F., Huang, K., Jiang, T., Zhou, X., Shi, Y., Ge, G., Shen, B. \& Zhai, J. Significantly enhanced energy storage density and efficiency of BNT-based perovskite ceramics via A-site defect engineering, Energy Storage Materials. 30, 392-400 (2020).

8. Shen, Z., Wang, X., Luo, B. \& Li, L. $\mathrm{BaTiO}_{3}-\mathrm{BiYbO}_{3}$ perovskite materials for energy storage applications. J. Mater. Chem. 3, 18146-18153 (2015). 
9. Yin, J., Zhang, Y., Lv, X., Wu, J. Ultrahigh energy-storage potential under low electric field in bismuth sodium titanate-based perovskite ferroelectrics. J. Mater. Chem. 6, 9823-9832 (2018).

10 Yuan, Q., Yao, F., Wang, Y., Ma, R. \& Wang, H. Relaxor ferroelectric 0.9BaTiO $3-$ $0.1 \mathrm{Bi}\left(\mathrm{Zn}_{0.5} \mathrm{Zr}_{0.5}\right) \mathrm{O}_{3}$ ceramic capacitors with high energy density and temperature stable energy storage properties. J. Mater. Chem. C. 5, 9552-9558 (2017).

11. Yang, Z., Gao, F., Du, H., Jin, L., Yan, L., Hu, Q., Yu, Y., Qu, S., Wei X., Xu, Z. \& Wangd, Y.J. Grain size engineered lead-free ceramics with both large energy storage density and ultrahigh mechanical properties. Nano Energy. 58, 768-777 (2019).

12. Zhu, C., Cai, Z., Luo, B., Cheng, X., Guo, L., Jiang, Y., Cao, X., Fu, Z., Li, L. \& Wang, X. Multiphase engineered BNT-Based ceramics with simultaneous high polarization and superior breakdown strength for energy storage applications. ACS Appl. Mater. Interfaces. 13, 28484-28492 (2021).

13. Cao, W.P., Li, W.L., Dai, X.F., Zhang, T.D., Sheng, J., Hou, Y.F.\& Fei, W. D. Large electrocaloric response and high energy-storage properties over a broad temperature range in lead-free NBT-ST ceramics. J. Eur. Ceram. Soc. 36, 593-600 (2016).

14. Ma, W., Zhu, Y., Marwat, M.A., Fan, P., Xie, B., Salamon, D., Ye, Z. G. \& Zhang, H. Enhanced energy-storage performance with excellent stability under low electric fields in BNT-ST relaxor ferroelectric ceramics. J. Mater. Chem. C. 7, 281-287 (2019).

15. Yan, F., Shi, Y., Zhou, X., Zhu, K., Shen, B., Zhai, J. Optimization of polarization and electric field of bismuth ferrite-based ceramics for capacitor applications. Chem. Eng. J. 417, 127945 (2021).

16. Huang, H. S., Chen, X.M., Lua, J.B. \& Lian, H. L. Ferroelectric and dielectric properties of KF-added $\left(\mathrm{K}_{0.48} \mathrm{Na}_{0.52}\right) \mathrm{NbO}_{3}$ lead-free ceramics. Physica B: Cond. Matt. 564, 28-32 (2019).

17. Liao, Y., Wang, D., Wang, H., Zhou, L., ji Zheng, Q., \& Lin D. Mdulation of defects and electrical behaviors in $\mathrm{Cu}$-doped $\mathrm{KNN}$ ceramics by fluorine-oxygen substitution. Dalton Trans. 4, 1311-1318 (2020).

18. Qiao, X.S., Chen, X.M., Lian, H.L., Zhou, J.P. \& Liu, P. Dielectric, ferroelectric, piezoelectric properties and impedance analysis of nonstoichiometric $\left(\mathrm{Bi}_{0.5} \mathrm{Na}_{0.5}\right)_{0.94+\mathrm{x}} \mathrm{Ba}_{0.06} \mathrm{TiO}_{3}$ ceramics. J. Eur. Ceram. Soc. 36, 3995 (2016).

19. Peng, P., Nie, H., Zheng, C., Wang, G. \& Dong, X. High-energy storage density in $\mathrm{NaNbO}_{3}$-modified $\left(\mathrm{Bi}_{0.5} \mathrm{Na}_{0.5}\right) \mathrm{TiO}_{3}-\mathrm{BiAlO}_{3}$-based lead-free ceramics under low electric field. J. Amer. Ceram. Soc. 104, 2610-2620 (2021).

20. Ma, J., Lin, Y., Yang, H., Tian, J. Achieved high energy storage property and power density in $\mathrm{NaNbO}_{3}-\mathrm{Bi}\left(\mathrm{Sn}_{0.5} \mathrm{Ni}_{0.5}\right) \mathrm{O}_{3}$ ceramics. J. All. Comp. 868, 159206 (2021).

21. Kornphom, C., Vittayakorn, N. \& Bongkarn, T. Lead-free piezoelectric ceramics based on (1-x)BNKLLT-xBCTZ binary solid solutions synthesized by the solid-state combustion technique. J. Mater. Sci. 51, $4142-4149$ (2016). 
22. Kornphom, C., Yotthuan, S., Kidkhunthod, P. \& Bongkarn, T. Stabilization of the morphotropic phase boundary in (1- x) BNT-xBCTS ceramics prepared by the solid-state combustion technique. Radiat. Phys. Chem. 188, 109638 (2021).

23 Guo, X., Shi, P., Lou, X., Liu, Q. \& Zuo, H. Superior energy storage properties in (1-x) $\left(0.65 \mathrm{Bi}_{0.5} \mathrm{Na}_{0.5} \mathrm{TiO}_{3}-0.35 \mathrm{Bi}_{0.2} \mathrm{Sr}_{0.7} \mathrm{TiO}_{3}\right)-\mathrm{xCaZrO}_{3}$ ceramics with excellent temperature stability. J. All. Comp. 876, 160101 (2021).

24. Ramkumar, T., Selvakumar, M., Vasanthsankar, R., Sathishkumar, A.S., Narayanasamy P. \& Girija, G. Rietveld refinement of powder X-ray diffraction, microstructural and mechanical studies of magnesium matrix composites processed by high energy ball milling, J. Magnes. Alloys. 6, 390-398 (2018).

25. Xu, Q., Lanagan, M.T., Huang, X., Xie, J., Zhang, L., Hao, H. \& Liu, H. Dielectric behavior and impedance spectroscopy in lead-free BNT-BT-NBN perovskite ceramics for energy storage. Ceram. Int. 42, 9728-9736 (2016).

26 Zang, J., Jo, W., Zhang, H. \& Rödel, J. $\mathrm{Bi}_{1 / 2} \mathrm{Na}_{1 / 2} \mathrm{TiO}_{3}-\mathrm{BaTiO}_{3}$ based thick-film capacitors for high-temperature applications. J. Eur. Ceram. Soc. 34, 37-43 (2014).

27. Acosta, M., Zang, J., Jo, W. \& Rödel, J. High-temperature dielectrics in $\mathrm{CaZrO}_{3}$-modified $\mathrm{Bi}_{1 / 2} \mathrm{Na}_{1 / 2} \mathrm{TiO}_{3}$-based lead-free ceramics. J. Eur. Ceram. Soc. 32, 4327-4334 (2012).

28. Yu, Z., Ang, C., Guon, R. \& Bhalla, A.S. Ferroelectric-relaxor behavior of $\mathrm{Ba}\left(\mathrm{Ti}_{0.7} \mathrm{Zr}_{0.3}\right) \mathrm{O}_{3}$ ceramics. J. Appl. Phys. 92, 2655-2657 (2002).

29. Shvartsman, V.V., Lupascu, D.C. \& Green, D.J. Lead-free relaxor ferroelectrics, J. Am. Ceram. Soc. 95, 1-26 (2012)

30. Yang, H., Yan, F., Lin, Y., Wang, T., Wang, F., Wang, Y., Guo, L., Tai, W. \& Wei, H. Lead-free $\mathrm{BaTiO}_{3}-\mathrm{Bi}_{0.5} \mathrm{Na}_{0.5} \mathrm{TiO}_{3}-\mathrm{Na}_{0.73} \mathrm{Bi}_{0.09} \mathrm{NbO}_{3}$ relaxor ferroelectric ceramics for high energy storage. J. Eur. Ceram. Soc. 37, 3303-3311 (2017).

31. Tao, H. \& Wu, J. Optimization of energy storage density in relaxor ( $\mathrm{K}, \mathrm{Na}, \mathrm{Bi}) \mathrm{NbO}_{3}$ ceramics, J. Mater. Sci: Mater. Elec. 28, 16199-16204 (2017).

32. Pu, Y., Zhang, L., Cui, Y. \& Chen, M. High energy storage density and optical transparency of microwave sintered homogeneous $\left(\mathrm{Na}_{0} .5 \mathrm{Bi}_{0.5}\right)(1-\mathrm{x}) \mathrm{Ba}_{\mathrm{x}} \mathrm{Ti}_{(1-\mathrm{y})} \mathrm{Sn}_{\mathrm{y}} \mathrm{O}_{3}$ ceramics, ACS Sustainable. Chem. Eng. 5, 6102-6109 (2018).

33. Zhang, L., Pu, Y., Chen, M., Wei, T. \& Peng, X., Novel $\mathrm{Na}_{0.5} \mathrm{Bi}_{0.5} \mathrm{Ti}_{0.5} \mathrm{O}_{3}$ based, lead-free energy storage ceramics with high powder and energy density and excellent high-temperature stability. Chem. Engineer. J. 383, 123154 (2020).

34. Li, Q., Yao, Z., Ning, L., Gao, S., Hu, B., Dong, G. \& Fan, H. Enhanced energy-storage properties of $(1-\mathrm{x})\left(0.7 \mathrm{Bi}_{0.5} \mathrm{Na}_{0.5} \mathrm{TiO}_{3}-0.3 \mathrm{Bi}_{0.2} \mathrm{Sr}_{0.7} \mathrm{TiO}_{3}\right)-\mathrm{xNaNbO}$ lead-free ceramics. Ceram. Int. 44, 2782-2788 (2018).

35. Wu, Y.J., Huang, Y.H., Wang, N., Li, J., Fu, M.S. \& Chen, X.M. Effects of phase constitution and microstructure on energy storage properties of barium strontium titanate ceramics. J. Eur. Ceram. Soc. 37, 2099-2104 (2017). 
36. Xie, J.L., Dai, Z.H., Ding, X.D., Fan, X., Liu, W.G., Zhang, L. \& Li, J.L. Enhanced energy storage properties of $\mathrm{Sr}\left(\mathrm{Sc}_{0.5} \mathrm{Nb}_{0.5}\right) \mathrm{O}_{3}$ modified $\left(\mathrm{Bi}_{0.47} \mathrm{La} \mathrm{La}_{0.03} \mathrm{Na}_{0.5}\right)_{0.94} \mathrm{Ba}_{0.06} \mathrm{TiO}_{3}$ lead-free ceramics, J. Mater. Sci. 55, 13578-13589 (2020).

37. Huang, Y., Li, F., Hao. H., Xia, F.Q., Liu, H. X. \& Zhang, S.J. $\left(\mathrm{Bi}_{0.51} \mathrm{Na}_{0.47}\right) \mathrm{TiO}_{3}$ based lead free ceramics with high energy density and efficiency. J. Materio. 5, 385-393 (2019). 